\title{
DESIGN OF BOOST CONVERTER BASED ON OPTIMUM WEIGHTED AVERAGE EFFICIENCY FOR PHOTOVOLTAIC SYSTEMS
}

\author{
Fernando Beltrame ${ }^{1}$, Fabrício H. Dupont ${ }^{2}$, Hamiltom C. Sartori ${ }^{2}$, Everton C. Cancian ${ }^{2}$, Leandro Roggia ${ }^{3}$, \\ José Renes Pinheiro ${ }^{2}$ \\ ${ }^{1}$ Federal Institute of Education, Science and Technology of Rio Grande do Sul (IFRS), IBIRUBÁ, RS - BRAZIL \\ ${ }^{2}$ Federal University of Santa Maria (UFSM), Power Electronics and Control Research Group, Santa Maria (GEPOC), RS - Brazil \\ ${ }^{3}$ Federal University of Santa Maria (UFSM), Industrial Technical College of Santa Maria, Santa Maria (CTISM), RS - Brazil \\ e-mail: engbeltrame@gmail.com, fhd@ieee.org, hamiltomsar@gmail.com,roggia@gmail.com, everton.cocco@gmail.com, \\ jrenes@gepoc.ufsm.br
}

\begin{abstract}
This paper presents different optimum designs of DC/DC boost converters applied to photovoltaic systems. Boost converter is employed as a maximum power point tracker. The main goal of this work is to select an operation point for this converter (current ripple (a) switching frequency), the magnetic core and conductor diameter, which provide better efficiency in all load range. The losses in capacitors, semiconductors and magnetics are evaluated for all load range. After that, it is obtained the efficiency in $5 \%, 10 \%, 25 \%, 50 \%, 75 \%$ and $100 \%$ of nominal power in order to calculate the weighted average efficiency, as determined by standard IEC 61683. From this evaluation, the operation point and the magnetic material that will result in the best efficiency are selected. The volume and cost are not considered in this work. Experimental results are presented to validate the simulated results, as well as the total efficiency results of the boost converter. Four different configurations are presented to prove that the operating point and the magnetic core selected are the best among them. A discussion of the results is presented, where alternatives to improve efficiency are analyzed.
\end{abstract}

Keywords - Boost Converter, Magnetic Core, Operation Point, Power Losses, Weighted Average Efficiency.

\section{INTRODUCTION}

In recent years, concern about the environment is becoming more popular, and rightly so. Media, governments and society seem to have woken up to the problem, perhaps because the recent natural events started with the tsunami in Asia, and continue succeeding with an impressive frequency. Solutions - or rather, measures - aimed at all levels are consistent: the pollution reduction. Today, according to the report published in 2012 by the International Energy Agency [1], electricity and heat generation were responsible for $41 \%$ of the world $\mathrm{CO}_{2}$ emissions. Worldwide, this sector relies heavily on coal, the most carbon-intensive of fossil fuels, amplifying its share in global emissions.

As shown in [1], countries such as Australia, China, India, Poland and South Africa produce between $68 \%$ and $94 \%$ of their electricity and heat through the combustion of coal. Future development of the emissions intensity of this sector depends strongly on the fuels used to generate electricity and

Manuscript submitted for publication 04/02/2014. First revision 28/04/2014, second revision 18/05/2014. Accepted for publication 22/06/2014 by recommendation of the editor Henrique A. C. Braga. on the share of non-emitting sources, such as renewable and nuclear as well as fossil-fuel plants equipped with carbon capture and storage technologies.

By 2035, the World Energy Outlook 2012 [2] projects that demand for electricity will be more than $70 \%$ higher than current demand. Therefore, the expansion of renewable energy sources will have a decisive influence on the ability to conduct the planet for way more safe, reliable and sustainable.

Among renewable energy sources, solar photovoltaic (PV) energy is one of the most plentiful throughout the Earth's surface and is endless in the human timescale. Therefore, it is one of the most promising alternatives for the composition of a new energy matrix worldwide [3]. It is expected that until 2040 this source will be the most important and significant renewable energy source for the world [4], [5].

However, the low conversion efficiency of solar cells and high installation costs are still major obstacles of this type of power generation. For example, crystalline silicon cells have efficiency in the range of $13 \%$ to $17 \%$ [3]. Therefore, it is of fundamental importance to extract the maximum power generated by the photovoltaic panels and ensure that the system operates as long as possible on the maximum power point. For this task, tracking systems are employed in order to track the maximum power point (MPPT). These systems vary dynamically the input impedance of the converters so that maximum power transfer is achieved.

Traditionally, a tracking system can be divided into two parts: a tracking algorithm, which receive information from the PV system (like voltage, current and temperature, etc.), performs the calculations and defines the best operating point; and one power stage, power converter, which ensures that the photovoltaic system operates at the point defined by algorithm [6]. Nowadays, the efficiency of these algorithms is usually above $99 \%$ [7]. So, the greatest impact on efficiency of a PV system is under responsibility of power converters, which are subject to constant variations in its operation point. For this reason, this work studies the design and efficiency optimization of a DC/DC boost converter, connected to a photovoltaic system, as shown in Figure 1.

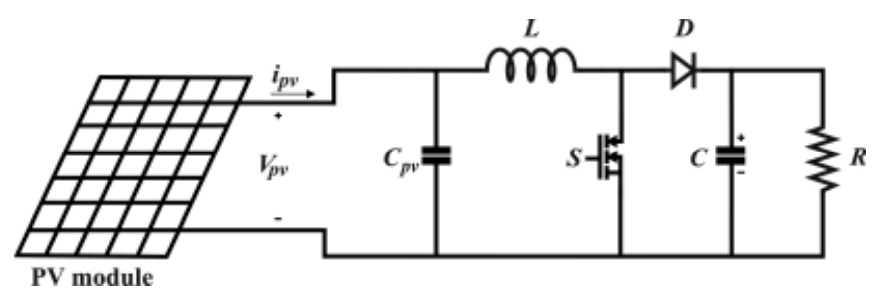

Fig. 1. Boost converter connected to the module performing as MPPT. 
Several studies investigate the optimization of converters with respect to volume, cost and efficiency [8]-[11]. Kolar et. al [8] say by 2030 will have an increase in electricity use by $50 \%$, whereas the generation will only increase to $38 \%$. A large fraction of this energy will subsequently be converted and conditioned by power electronics systems. Thus, in view of the low generation efficiency, the energy efficiency of the power electronics converters will get eminent importance.

However, the authors affirm that the reduction of the initial costs or increase of power density have been of primary concern. Efficiency increase was only indirectly required, since a lower system volume provides a smaller surface for power loss dissipation. Thinking about it, the compromise between maximum efficiency and maximum power density by choosing the switching frequency of the converter is investigated [8], [9]. The design selects the optimum operation point to the rated power.

On the other hand, in others works [10], [11], the volume optimization of the boost converter operating as power factor correction (PFC) is achieved through the choice of the operating point ( $\left.\Delta i @ f_{S}\right)$ and selection of core type. Again, the design is performed at rated power.

Thus, this paper proposes the efficiency optimization of boost DC/DC converter through the operating point selection and core type. The converter design will select the optimum operation point according to solar irradiation curve for the annual occurrence in the region of São Martinho da Serra, RS, Brazil, using the weighted average efficiency presented in [5]. The volume and cost are not considered in this work.

Thus, firstly, the paper introduces the concept of weighted average efficiency. Then, the work investigates the losses in all elements of the boost converter using equations already established in the literature, with experimental validation of these calculations. After that, it is shown, step by step, the magnetic and operating point selection, that results in the best weighted average efficiency. Experimental results are obtained to prove the operating point selected is the best among the considered points.

\section{WEIGHTED AVERAGE EFFICIENCY}

As stated previously, some works design the converter to have a maximum efficiency at $100 \%$ load. In the case of an application where the converter will always operate at $100 \%$ load, this operating point may be optimum. However, if this converter is connected to photovoltaic panels, few times in the year this converter will operate at $100 \%$ load.

Figure 2 presents data from the meteorological station of São Martinho da Serra irradiation, where the maximum and average values can be viewed over a year [5].

So, which is the point of load the converter shall have a maximum efficiency? Figure 3, also presented in [5], can answer this question. This figure shows the energy available, by year, for each irradiation and percentage hours of annual occurrence of this irradiation in São Martinho da Serra. Through Figure 3, it is possible to conclude the higher occurrence of irradiation, over a year, occurs between 400 $\mathrm{W} / \mathrm{m}^{2}$ and $600 \mathrm{~W} / \mathrm{m}^{2}$. It is interesting that a converter applied to this PV system presents maximum efficiency in this range. That will result in a better utilization of the available energy.

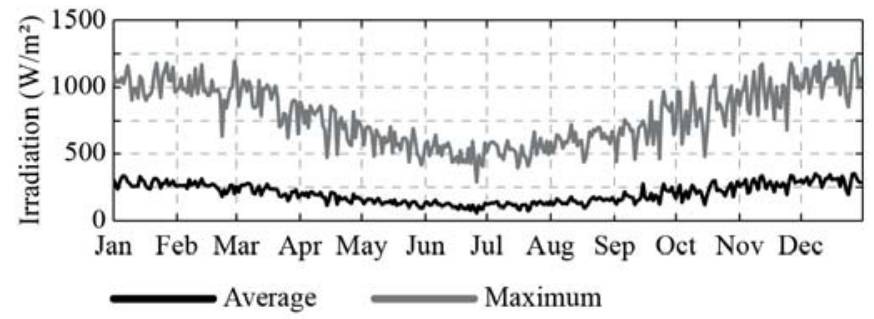

Fig. 2. Average and maximum daily values of global irradiation to the São Martinho da Serra station [5].

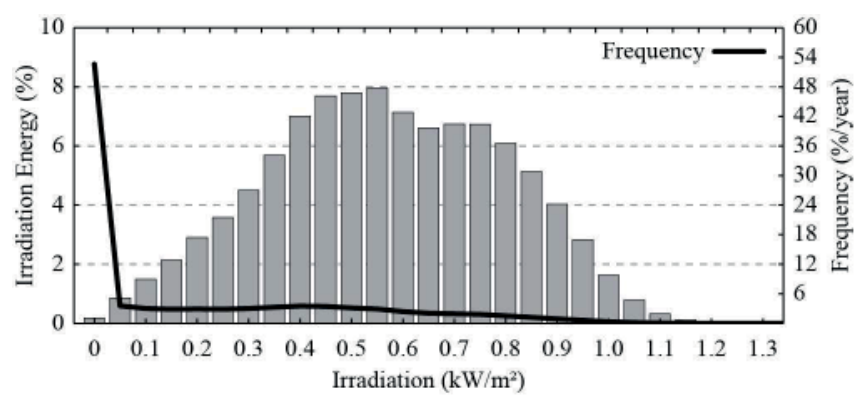

Fig. 3. Energy available, over year, for each irradiation range and the hours percentage of annual occurrence in São Martinho da Serra/RS.

Then, the present work has as goal to select an operation point resulting in better efficiency, in all power operating range of the photovoltaic panel. The design will be realized with use of the weighted average efficiency concept, which is established by IEC 61683 [12].

Weighted average efficiency is a figure of merit that represent the power converter efficiency for different operation points in function of time that it operates at each point. The standard IEC 61683 establishes the basic procedures for evaluating the weighted average efficiency or power converters connected to PV modules, taking into account the characteristics of the variability in operating point depending on meteorological conditions.

Thus, from the analysis of statistical data of the weather conditions in certain regions of the world, irradiation profiles over a year, and taking into account the concept of weighted average efficiency, efficiency from every region are obtained. Thinking about it, Dupont [5] proposes the weighted average efficiency for annual average irradiation condition for the region of the São Martinho da Serra station, RS, given by:

$$
\begin{aligned}
& \eta=0.01 \eta_{5 \%}+0.15 \eta_{10 \%}+0.37 \eta_{25 \%}+0.33 \eta_{50 \%}+\ldots \\
& 0.13 \eta_{75 \%}+0.01 \eta_{100 \%}
\end{aligned}
$$

The IEC 61683 standard requires the converters should be evaluated operating at $5 \%, 10 \%, 25 \%, 50 \%, 75 \%$ and $100 \%$ of full power and the values shown in (1) are weighting constants that represent the portion of time in which the converter operates in a given power.

Therefore, it can be concluded that in São Martinho da Serra, one converter connected to a PV panel will operate approximately $70 \%$ of the time with a power ranging between $25 \%$ and $50 \%$ of full load. 


\section{LOSSES CALCULATION}

To obtain the theoretical efficiency of the boost converter coupled to the PV panel, the following losses were considered.

\section{A. Capacitor Losses}

Output capacitor losses are mainly caused by ohmic losses in the equivalent series resistance $\left(R_{E S R}\right)$. This resistance is depending on temperature $(\theta)$ and switching frequency $\left(f_{s}\right)$, and the capacitor losses are obtained by:

$$
P_{\text {cap }}=\frac{\omega}{2 \pi} \int_{0}^{2 \pi / \omega} i_{\text {cap }}^{2}(t) R_{E S R}\left(f_{s}, \theta\right) d t
$$

where $i_{c a p}$ is the capacitor current.

\section{B. Magnetic Losses}

Magnetic losses of the boost inductor are divided in core losses and cooper losses.

1) Core losses - The core losses are usually estimated through curves provided by the manufacturer [13]. These losses are generated by magnetic flux variation within the material. Such losses are dependent on the magnetic flux density $\left(B_{p k}\right)$, core volume $\left(V_{\text {core }}\right)$, switching frequency $\left(f_{s}\right)$ and constants $(a, b, c)$, provided in the datasheet of the magnetic core, as follow:

$$
P_{\text {core }}=V_{\text {core }} a B_{p k}^{b} f_{s}^{c} .
$$

2) Copper losses - Copper losses depend mainly on three factors: losses caused by material resistivity (DC resistance), by the skin effect and by the proximity effect (AC resistance) [14], [15]. The DC resistance is defined by the electrical resistivity $(\rho)$, the conductor length $\left(w_{l}\right)$ and cross-section area of the conductor $\left(A_{w}\right)$, being calculated by:

$$
R_{d c}=\frac{\rho w_{l}}{A_{w}}
$$

On the other hand, the AC resistance depends on the amplitude and frequency of the current flowing through the conductor, and can be approximate by (5) [14], which apply only to toroidal cores.

$$
R_{a c}(f)=\left(\frac{4}{\pi}\right)^{\frac{1}{4}} N l_{e s p} \sqrt{\frac{\rho \mu \pi f}{d t_{d}}}\left(1+\frac{2\left(N_{l}^{2}-1\right)}{3}\right)
$$

where:

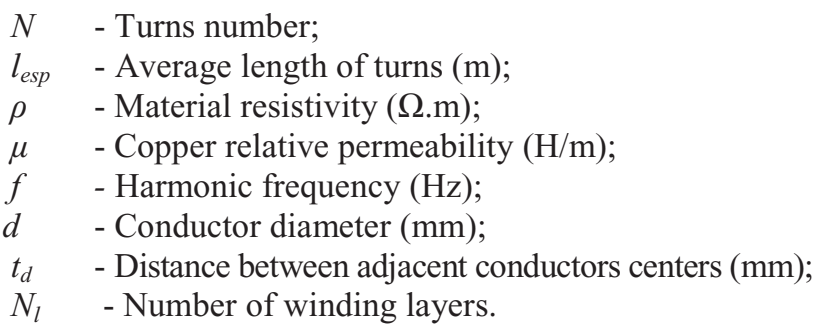

Thus, the cooper losses are calculated by the sum of DC and $\mathrm{AC}$ losses as:

$$
P_{\text {copper }}=R_{d c} i_{L(r m s)}^{2}+\sum_{f=0}^{\infty}\left(R_{a c}(f) i_{L}(f)^{2}\right)
$$

being $i_{L(\mathrm{rms})}$ is the rms current and $i_{L}(f)$ the harmonic current.

\section{Semiconductor Losses}

The method used for semiconductor losses consists in performing the estimation of conduction and switching losses based on the datasheet information from semiconductor devices. The conduction losses are calculated as a function of the voltage drop that occurs while the semiconductor device is conducting. This voltage drop is dependent on the current and temperature, and it is obtained from the charts available on semiconductor datasheets [16].

Usually, the datasheets have three sets of these charts, one for each junction temperature (generally 25,150 and $175^{\circ} \mathrm{C}$ ) for the power semiconductor. Thus, if the current is known, one can employ numerical methods to interpolate these curves and estimate the power dissipated by the component for any junction temperature. From these values, conduction losses of the power diode can be determined by:

$$
P_{\text {cond }}=\frac{1}{T_{s}} \int_{0}^{T_{s}} V_{f}\left(I_{f}, \theta\right) I_{f}(t) d t
$$

where $V_{f}$ is the semiconductor voltage drop and $I_{f}$ is the forward current. In the MOSFET case, the conduction losses can be determined based on its conduction resistance. However, the resistance curves, provided by the manufacturers, are usually given for a single operating point. Therefore, in this paper the method proposed in [17] is used, which employs the charts of drain-source current and voltage to estimate the conduction losses. This method may provide better results, since manufacturers generally provide two sets of these charts, one for each junction temperature (typically $25^{\circ} \mathrm{C}$ and $150^{\circ} \mathrm{C}$ ).

On the other hand, switching losses are obtained by identification of each switching transition and calculated as shown in [17] by means of:

$$
P_{o n}=\frac{1}{2} i_{d e v} V_{o} t_{r} f_{s}+\frac{1}{2} C_{o s s} V_{o}^{2} f_{s}
$$

for turn-on, and

$$
P_{\text {off }}=\frac{1}{2} i_{d e v} V_{o} t_{f} f_{s}
$$

for turn-off, where:

$i_{d e v}$ - Current in the semiconductor at the switching instant (A);

$V_{o}$ - Voltage over the semiconductor device (V);

$t_{r}$ - Rise time (s);

$t_{f}$ - Fall time (s);

$C_{\text {oss }}$ - Output capacitance of the switch (F).

In the diode case, switching losses are calculated according to diode reverse recovery current, $I_{r r}$, defined by: 


$$
I_{r r}=\frac{2 Q_{r r}}{t_{r r}}
$$

This current depends on stored reverse recovery charge $\left(Q_{r r}\right)$, and the reverse recovery time $\left(t_{r r}\right)$. Both $Q_{r r}$ and $t_{r r}$ are obtained in the semiconductor datasheet, and also require the interpolation charts, since most manufacturers present the charts junction temperatures of $25^{\circ} \mathrm{C}$ and $125^{\circ} \mathrm{C}$. The $Q_{r r}$ value is directly proportional to the diode forward current, and the diode junction temperature. So, with these values, it is possible to calculate the power dissipated during the diode reverse recovery as demonstrated by [18] by means of:

$$
P_{o f f \_ \text {diode }}=Q_{r r}\left(I_{f}, \theta\right) V_{o} f_{s} .
$$

So, with the losses defined, it is interesting to find out the exact temperature that the semiconductor will operate, so it is necessary to find the temperature rise of each device.

For semiconductors, the temperature rise is determined as shown in [19], by analyzing the thermal equivalent circuit depicted by Figure 4. In this case, the switch and diode are mounted on the same heatsink. Thus, the heatsink temperature is considered the same for each semiconductor [18], and is obtained by:

$$
T_{\text {Heatsink }}=T_{A}+R_{\theta_{D A}}\left(P_{S}+P_{d}\right) .
$$

The case temperature of the power transistor is obtained by:

$$
T_{C_{S}}=T_{J_{S}}-P_{S} R_{S_{-} \theta_{J C}}
$$

while the case temperature of the diode is estimated by:

$$
T_{C_{d}}=T_{J_{d}}-P_{d} R_{d_{-} \theta_{J C}}
$$

where:

$$
\begin{aligned}
& T_{J S} \quad \text { - Junction temperature of switch }\left({ }^{\circ} \mathrm{C}\right) ; \\
& T_{J d} \quad \text { - Junction temperature of diode }\left({ }^{\circ} \mathrm{C}\right) ; \\
& T_{A} \quad \text { - Ambient temperature }\left({ }^{\circ} \mathrm{C}\right) ; \\
& R_{S \_\theta J C} \text { - Junction to case thermal resistance of switch }\left({ }^{\circ} \mathrm{C} / \mathrm{W}\right) ; \\
& R_{d \_\theta J C} \text { - Junction to case thermal resistance of diode }\left({ }^{\circ} \mathrm{C} / \mathrm{W}\right) ; \\
& R_{\theta D A} \text { - Heatsink thermal resistance }\left({ }^{\circ} \mathrm{C} / \mathrm{W}\right) ; \\
& P_{S} \quad \text { - Dissipation losses by switch }(\mathrm{W}) ; \\
& P_{d} \quad \text { - Dissipation losses by diode }(\mathrm{W})
\end{aligned}
$$

For the magnetic, the temperature rise is established by manufacturer [13] through the empirical equation:

$$
\Delta T_{\text {Magnetic }}=\left(\frac{P_{\text {core }}+P_{\text {copper }}}{A_{\text {ext }}}\right)^{0.833}
$$

knowing the external area $\left(A_{\text {ext }}\right)$ of the magnetic core.

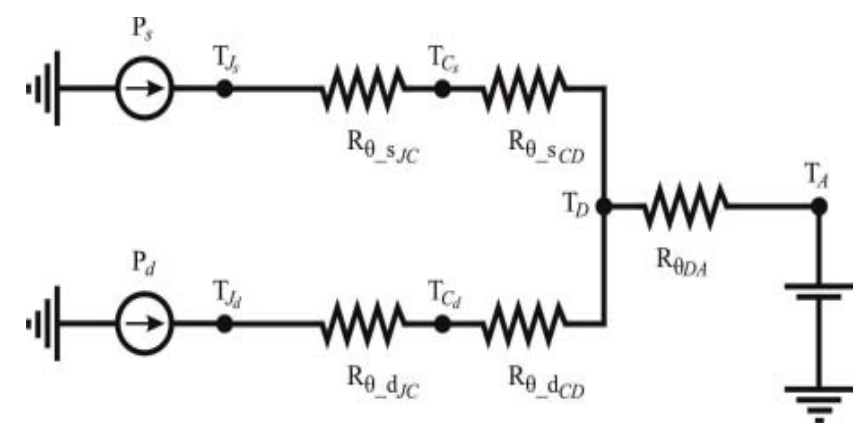

Fig. 4. Equivalent thermal circuit for two semiconductor devices mounted on the same heatsink.

\section{EXPERIMENTAL VALIDATION}

Experimental results were obtained in order to validate the losses calculation. Then, a boost converter was implemented using the specifications shown in Table I. A single heatsink for both semiconductor devices has been used, and no insulation was introduced between the semiconductors and the heatsink to avoid an unmodeled thermal resistance. The toroidal inductor was designed to obtain single layer and the gate resistance is $10 \Omega$.

The experimental validation of the calculation losses was performed obtaining the converter efficiency, the magnetic and heatsink temperature. Efficiency has been measured by a Yokogawa WT1800, while temperature by thermal camera Fluke Ti 20 - Thermal Imager. The temperature of magnetic and heatsink were observed until they became stable, for 14 operating points. Load power, switching frequency, input voltage and duty cycle were changed.

Table II presents a comparison of the obtained efficiencies between the experimental and simulation results. The average error between experimental and simulation results is about $0.2 \%$.

On the other hand, the magnetic temperature are showed in Table III, for the same 14 test points. The average error between the simulated and experimental results for the inductor was around $3.73 \%$. This difference between the results can be attributed to the approximations that are made in the simulation calculations. Moreover, the calculation of the temperature rise is accomplished by an empirical equation that uses a simplified model.

TABLE I

Prototype Specifications

\begin{tabular}{cc}
\hline Boost inductor & $122 \mu \mathrm{H}$ \\
\hline Core type & Kool M $\mu$ \\
\hline Part Number of core & $1 \times 77908$ \\
\hline Turns number & 50 turns (single layer) \\
\hline Conductor number & 27 conductors \\
\hline Conductors type & AWG 27 \\
\hline Output Capacitor & $4 \times 220 \mu \mathrm{H}(\mathrm{B} 43504-\mathrm{A} 5227-\mathrm{M})$ \\
\hline MOSFET & IRFP 460A \\
\hline Diode & $15 \mathrm{ETH} 06$ \\
\hline Heatsink type & HS 10425 \\
\hline Heatsink length & $13 \mathrm{~cm}$
\end{tabular}


TABLE II

Converter Efficiency - Simulated and Experimental Results

\begin{tabular}{|c|c|c|c|}
\hline \multirow{2}{*}{$\begin{array}{c}\text { Load - frequency }(\mathrm{Hz}) \text { - } \\
\text { duty-cycle }\end{array}$} & \multicolumn{2}{|c|}{ Efficiency (\%) } & \multirow{2}{*}{$\begin{array}{c}\text { Error } \\
\%\end{array}$} \\
\hline & Simulated & Experimental & \\
\hline $300 \mathrm{~W}-75 \mathrm{k}-0.7$ & 97.11 & 97.00 & 0.11 \\
\hline $400 \mathrm{~W}-75 \mathrm{k}-0.7$ & 96.79 & 96.76 & 0.03 \\
\hline $500 \mathrm{~W}-75 \mathrm{k}-0.7$ & 96.70 & 96.61 & 0.09 \\
\hline $600 \mathrm{~W}-75 \mathrm{k}-0.7$ & 96.60 & 95.90 & 0.72 \\
\hline $700 \mathrm{~W}-75 \mathrm{k}-0.7$ & 96.00 & 95.30 & 0.73 \\
\hline $500 \mathrm{~W}-75 \mathrm{k}-0.5$ & 97.71 & 97.76 & 0.05 \\
\hline $600 \mathrm{~W}-75 \mathrm{k}-0.5$ & 97.76 & 97.79 & 0.03 \\
\hline $800 \mathrm{~W}-75 \mathrm{k}-0.5$ & 97.78 & 97.72 & 0.06 \\
\hline $500 \mathrm{~W}-75 \mathrm{k}-0.25$ & 98.60 & 98.72 & 0.13 \\
\hline $700 \mathrm{~W}-75 \mathrm{k}-0.25$ & 98.68 & 98.77 & 0.09 \\
\hline $400 \mathrm{~W}-50 \mathrm{k}-0.7$ & 96.71 & 96.73 & 0.02 \\
\hline $600 \mathrm{~W}-50 \mathrm{k}-0.7$ & 96.61 & 96.71 & 0.10 \\
\hline $500 \mathrm{~W}-50 \mathrm{k}-0.5$ & 97.39 & 97.46 & 0.07 \\
\hline $400 \mathrm{~W}-50 \mathrm{k}-0.25$ & 98.43 & 98.58 & 0.15 \\
\hline
\end{tabular}

TABLE III

Magnetic Temperature - Simulated and Experimental Results

\begin{tabular}{ccccc}
\hline Load - frequency & \multicolumn{2}{c}{ Temperature $\left({ }^{\mathbf{0}} \mathbf{C}\right)$} & \multicolumn{2}{c}{ Error } \\
\cline { 2 - 5 }$(\mathbf{H z})$ - duty-cycle & Simulated & Experimental & ${ }^{\mathbf{0}} \mathbf{C}$ & $\%$ \\
\hline $300 \mathrm{~W}-75 \mathrm{k}-0.7$ & 37.40 & 37.1 & 0.30 & 0.80 \\
\hline 400W - 75k-0.7 & 38.40 & 36.5 & 1.90 & 4.95 \\
\hline $500 \mathrm{~W}-75 \mathrm{k}-0.7$ & 39.20 & 38.4 & 0.80 & 2.04 \\
\hline $600 \mathrm{~W}-75 \mathrm{k}-0.7$ & 41.00 & 38.8 & 2.20 & 5.37 \\
\hline $700 \mathrm{~W}-75 \mathrm{k}-0.7$ & 41.80 & 40.6 & 1.20 & 2.87 \\
\hline $500 \mathrm{~W}-75 \mathrm{k}-0.5$ & 38.00 & 35.8 & 2.20 & 5.79 \\
\hline $600 \mathrm{~W}-75 \mathrm{k}-0.5$ & 40.70 & 40.5 & 0.20 & 0.49 \\
\hline $800 \mathrm{~W}-75 \mathrm{k}-0.5$ & 44.10 & 41.7 & 2.40 & 5.44 \\
\hline $500 \mathrm{~W}-75 \mathrm{k}-0.25$ & 32.00 & 30 & 2.00 & 6.25 \\
\hline $700 \mathrm{~W}-75 \mathrm{k}-0.25$ & 34.60 & 33.1 & 1.50 & 4.34 \\
\hline $400 \mathrm{~W}-50 \mathrm{k}-0.7$ & 41.63 & 42.7 & 1.07 & 2.57 \\
\hline $600 \mathrm{~W}-50 \mathrm{k}-0.7$ & 49.20 & 47.7 & 1.50 & 3.05 \\
\hline $500 \mathrm{~W}-50 \mathrm{k}-0.5$ & 39.20 & 38.7 & 0.50 & 1.28 \\
\hline $400 \mathrm{~W}-50 \mathrm{k}-0.25$ & 33.20 & 30.9 & 2.30 & 6.93 \\
\hline
\end{tabular}

TABLE IV

Heatsink Temperature - Simulated and Experimental Results

\begin{tabular}{ccccc}
\hline Load - frequency & \multicolumn{2}{c}{ Temperature $\left({ }^{\mathbf{0}} \mathbf{C}\right)$} & \multicolumn{2}{c}{ Error } \\
\cline { 2 - 5 }$(\mathbf{H z})-$ duty-cycle & Simulated & Experimental & ${ }^{\mathbf{o}} \mathbf{C}$ & $\mathbf{\%}$ \\
\hline 300W - 75k - 0.7 & 37 & 36.8 & 0.18 & 0.49 \\
\hline $400 \mathrm{~W}-75 \mathrm{k}-0.7$ & 43 & 42.8 & 0.21 & 0.49 \\
\hline $500 \mathrm{~W}-75 \mathrm{k}-0.7$ & 48 & 48.9 & 0.90 & 1.88 \\
\hline $600 \mathrm{~W}-75 \mathrm{k}-0.7$ & 58 & 60.2 & 2.20 & 3.80 \\
\hline $700 \mathrm{~W}-75 \mathrm{k}-0.7$ & 68 & 72.6 & 4.57 & 6.71 \\
\hline $500 \mathrm{~W}-75 \mathrm{k}-0.5$ & 43 & 41.9 & 1.09 & 2.54 \\
\hline $600 \mathrm{~W}-75 \mathrm{k}-0.5$ & 45 & 43.6 & 1.41 & 3.13 \\
\hline $800 \mathrm{~W}-75 \mathrm{k}-0.5$ & 50 & 48.9 & 1.06 & 2.12 \\
\hline $500 \mathrm{~W}-75 \mathrm{k}-0.25$ & 37 & 34.9 & 2.14 & 5.79 \\
\hline $700 \mathrm{~W}-75 \mathrm{k}-0.25$ & 40 & 38.5 & 1.47 & 3.68 \\
\hline $400 \mathrm{~W}-50 \mathrm{k}-0.7$ & 44 & 44.9 & 0.86 & 1.95 \\
\hline $600 \mathrm{~W}-50 \mathrm{k}-0.7$ & 54 & 54.7 & 0.73 & 1.35 \\
\hline $500 \mathrm{~W}-50 \mathrm{k}-0.5$ & 48 & 48.6 & 0.57 & 1.20 \\
\hline $400 \mathrm{~W}-50 \mathrm{k}-0.25$ & 38 & 37.9 & 0.12 & 0.32 \\
\hline
\end{tabular}

Following the analysis, Table IV presents the results of the heatsink temperature. The average error between the simulated and experimental results for the heatsink is about $2.4 \%$. Again, this difference between the results is attributed to considered simplifications. Moreover, it is not possible to ensure the perfect contact between the semiconductor and the heatsink, and the use of thermal grease inserts a thermal resistance between them. Such resistance is difficult to be quantified, since it is hard to measure the thickness of the grease layer. Also, it is worth to notice the warning of the heatsink manufacturer [20], which states:

"Warning: All information contained in this catalog is only qualitative indicators of the heatsinks and it should not be considered absolute truths. The thermal resistance values depend on the heatsink position and external environment. Physical measurements (dimensions) may vary and they are also subject to change without previously warning."

Therefore, it can be said that the results obtained by simulation are close to reality, since several details are not possible to be considered.

\section{CHOICE OF THE OPTIMAL OPERATION POINT}

After the validation of the losses estimation procedure, a computer program for selection of the optimal operation point has been developed. By means of simulation of various operating points, it is possible to find the optimal one that minimizes losses and to improve the overall efficiency of the converter. Thus, it was developed an algorithm that tracks the operating points of the boost converter and selects the frequency, ripple and magnetic core that result the low losses.

The semiconductors presented in Table I and seven toroidal cores of type Kool $\mathrm{M} \mu$ have been considered. For the input stage, three photovoltaic panels model KD210GXLPD of Kyocera are connected in series, which results in an output of $600 \mathrm{~W}$ at Standard Test Conditions (STC). The output voltage at the maximum power point for this panel configuration is around $75 \mathrm{~V}$ which in turn requires an output voltage of $340 \mathrm{~V}$.

The developed algorithm selects the magnetic material, the conductors and number of conductors (considering the skin effect). At the end of the process, it is selected the operating point which results in better efficiency, by analyzing the weighted average efficiency.

The following step-by-step procedure describes how the operating point selection occurs:

$\mathbf{1}^{\text {st }}$ Step: Sets the range of switching frequency and current ripple that the program will track the operating point.

$2^{\text {nd }}$ Step: Define the number of stacked cores that are considered, as well as the initial temperature of magnetic and semiconductors.

$3^{\text {rd }}$ Step: For each pair $\left(\Delta_{i} @ f_{s}\right)$, it is calculated the inductance of the boost inductor using (16). After that, it is obtained the energy stored in this inductor according to (17), for the choice of the all possible magnetic cores that will be used. This magnetic selection follows the procedures reported by [13] on the Core Selector Chart. For each operation point, more than one magnetic core is tested. 


$$
\begin{aligned}
& L=\frac{V_{\text {in }} d(t)}{2 \Delta i f_{s}} \\
& E=L I_{L_{p r o j}}^{2}
\end{aligned}
$$

where:

$V_{\text {in }} \quad$ - Input voltage (V);

$d(t)$ - Duty-cycle of boost converter;

$I_{\text {Lproj }}$ - Design current (A).

$4^{\text {th }}$ Step: Turns number is calculated for all cores selected for each operating point.

$5^{\text {th }}$ Step: Determine the conductor type (AWG) and the conductors number, taking into account skin effect and proximity effect. It is selected the conductor which results in the smaller resistance.

$6^{\text {th }}$ Step: Magnetic losses are estimated, considering the stipulated initial temperature. At the end of this step, it is calculated the temperature rise of the magnetic. If this temperature is different from the stipulated initial temperature, recalculates the losses using this new temperature. This step finishes when the real temperature is found.

$7^{\text {th }}$ Step: Calculate the weighted average efficiency considering only the magnetic losses, for each operation point, and for all cores selected.

$8^{\text {th }}$ Step: It is selected the core that results in the higher weighted average efficiency for each operation point.

$9^{\text {th }}$ Step: Semiconductors losses are calculated. As shown earlier, the semiconductors losses are directly proportional to temperature. Therefore, the losses are calculated considering the stipulated initial temperature. At the end of this calculation, the temperature in each semiconductor is calculated. If this temperature is different from the stipulated initial temperature, recalculate the losses until the real temperature be found.

$10^{\text {th }}$ Step: The output capacitor losses are calculated.

$11^{\text {st }}$ Step: With the capacitor losses, semiconductors losses and the magnetic losses (from the core selected), theoretical efficiency is estimated in the load points defined by weighted average efficiency equation $(5 \%, 10 \%, 25 \%$, $50 \%, 75 \%$ and $100 \%$ of load).

$12^{\text {nd }}$ Step: For each operation point the weighted average efficiency is obtained.

$13^{\text {rd }}$ Step: It is plotted a figure where it is possible to analyze the weighted average efficiency behavior in the considered points.

$14^{\text {th }}$ Step: To end, it is selected the operating point which results in the best efficiency among the analyzed points and with the semiconductors and cores considered.

Figure 5 illustrates the weighted average efficiency behavior considering $5 \%$ to $35 \%$ for current ripple and the switching frequency range of $5 \mathrm{kHz}$ to $95 \mathrm{kHz}$. It is highlighted in Figure 5 the operation point 20\%@15 kHz. This point was selected as being the optimum point to the materials used and the intervals of frequency and current ripple considered.

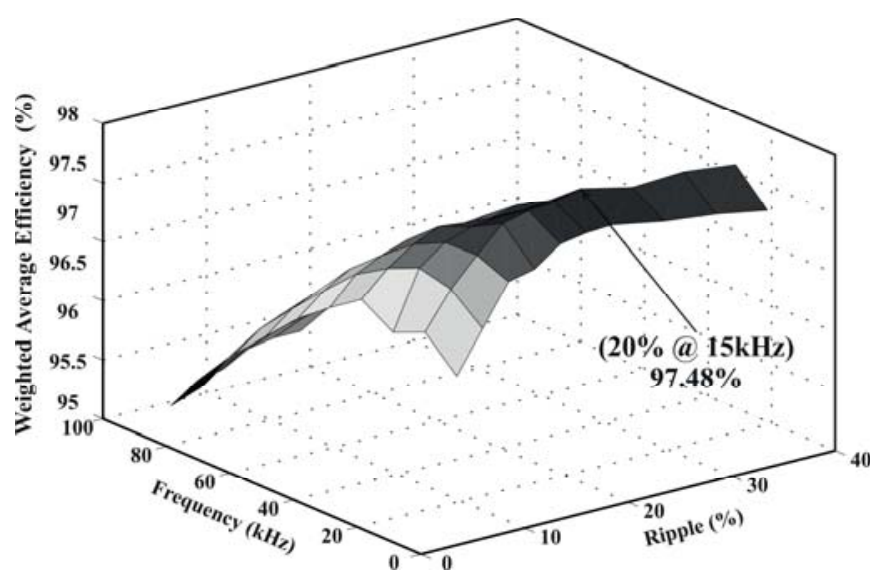

Fig. 5. Weighted average efficiency considering Kool M $\mu$ core.

It was considered only seven core of Kool M $\mu$ type, the cores available at the laboratory, and the semiconductors and capacitors presented in Table I. If others semiconductors and cores types were used, the weighted average efficiency could be improved, and other operation point could be selected.

\section{EXPERIMENTAL RESULTS}

The validation of the algorithm presented in the previous section is conducted experimentally. The better operating point is illustrated in Table $\mathrm{V}$, together with the magnetic core and conductor selected. Three other operating points, around the selected point, were also evaluated in order to prove that the selected operation point provides the best result indeed.

These four experimental results were obtained using a DC/DC source, and Table VI shows the experimental results obtained. A comparison between experimental and simulated result is presented. The experimental results were very satisfactory, since the percentage error between the simulated and experimental values were low. Furthermore, it can be noticed by Table VI that the selected operation point is the best among them.

Figure 6 illustrates the efficiency curve of the first operation point selected, for experimental and simulation results, where it is possible to check the values are close and the experimental curve follows the behavior of the simulated curve.

TABLE V

Data from Operation Point Evaluated

\begin{tabular}{ccccc}
\hline & $\mathbf{1}^{\text {st }}$ Point & $\mathbf{2}^{\text {nd }}$ Point & $\mathbf{3}^{\text {rd }}$ Point & $\mathbf{4}^{\text {th }}$ Point \\
\hline $\begin{array}{c}\text { Weighted average } \\
\text { efficiency }\end{array}$ & $97.48 \%$ & $97.38 \%$ & $97.23 \%$ & $97.12 \%$ \\
\hline Switching Frequency & $15 \mathrm{kHz}$ & $15 \mathrm{kHz}$ & $25 \mathrm{kHz}$ & $25 \mathrm{kHz}$ \\
\hline Current Ripple & $20 \%$ & $25 \%$ & $20 \%$ & $30 \%$ \\
\hline Inductance & $2.5 \mathrm{mH}$ & $2 \mathrm{mH}$ & $1.5 \mathrm{mH}$ & $1 \mathrm{mH}$ \\
\hline Part Number Core & 77908 & 77908 & 77908 & 77908 \\
\hline Cores & 3 & 3 & 3 & 3 \\
\hline Turns number & 167 & 147 & 125 & 101 \\
\hline Conductor number & 3 & 3 & 4 & 4 \\
\hline Conductors (AWG) & 18 & 18 & 20 & 20 \\
\hline & & & &
\end{tabular}


TABLE VI

Comparison Results

\begin{tabular}{lccc}
\hline Operation Point & Simulated & Experimental & Error \\
\hline $\mathbf{( 2 0 \% @ 1 5 ~ k H z )}$ & $97.48 \%$ & $96.87 \%$ & $0.61 \%$ \\
\hline $\mathbf{( 2 5 \% @ 1 5 ~ k H z )}$ & $97.38 \%$ & $96.84 \%$ & $0.55 \%$ \\
\hline $\mathbf{( 2 0 \% @ 2 5 ~ k H z )}$ & $97.23 \%$ & $96.7 \%$ & $0.53 \%$ \\
\hline $\mathbf{3 0 \% @ 2 5 ~ k H z )}$ & $97.12 \%$ & $96.69 \%$ & $0.43 \%$ \\
\hline
\end{tabular}

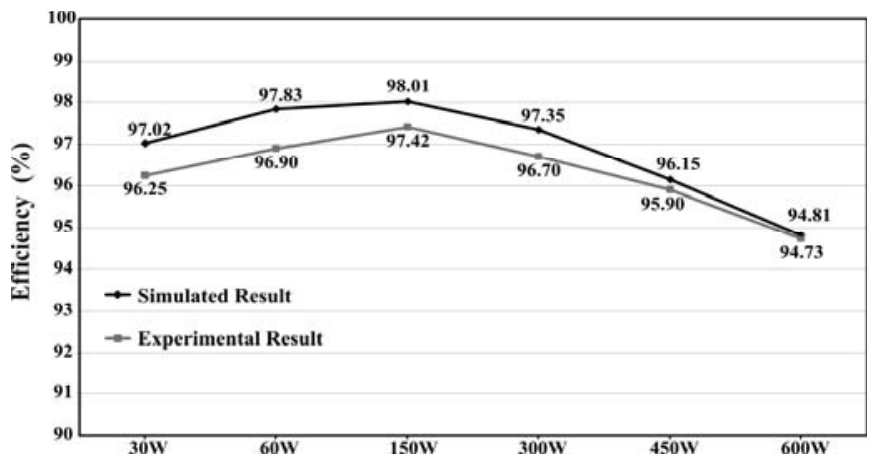

Fig. 6. Comparison of efficiency curve for experimental and simulated results at the $20 \% @ 15 \mathrm{kHz}$.

Now, from detailed losses analysis of the best operation point selected, some conclusions can be obtained to increase the efficiency of this converter. The values present in Figure 7 to Figure 10 are simulated results and the percentage values illustrated in figures are the weighting constants from (1).

Figure 7 illustrates the percentage losses of this operation point, and it can be noticed the magnetic material losses are most significant in five load points $(30 \mathrm{~W}, 60 \mathrm{~W}, 150 \mathrm{~W}, 300$ $\mathrm{W}$ and $450 \mathrm{~W}$ ). These load points represent a huge part of final result.

Analyzing Figure 8, it can be seen that these magnetic losses are mainly copper losses. The simple solution would be to decrease the wire length or put more wires in parallel. Increasing the number of wires is not a very satisfactory solution, since this will affect the volume of the inductor. On the other hand, the decrease in wire length is possible by using another magnetic material, which has high magnetic permeability, such as high flux material. With high permeability is possible to get the same magnetic, with desired inductance, using a reduced number of turns.

For the semiconductors case, from Figure 7 , it can be checked that they have the highest losses, especially for load situations that have more contribution in the weighted average efficiency $(150 \mathrm{~W}, 300 \mathrm{~W}$ and $450 \mathrm{~W})$. In Figures 9 and 10 , it can be observed the behavior of the semiconductor losses by conduction and switching. A significant efficiency improvement could be obtained if others semiconductors were used, especially, with low conduction losses.

\section{CONCLUSION}

This work presented a design of boost converter applied to photovoltaic system based on weighted average efficiency. Optimum weighted average efficiency of the boost converter has been possible to be achieved by the selections of operation point (current ripple @ switching frequency) and magnetic core.

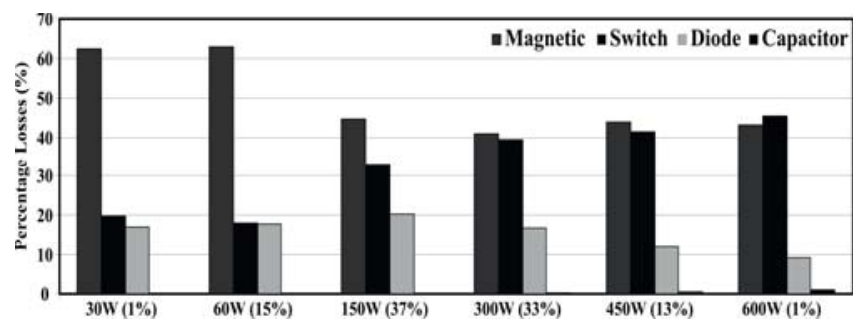

Fig. 10. Percentage losses of all components considered.

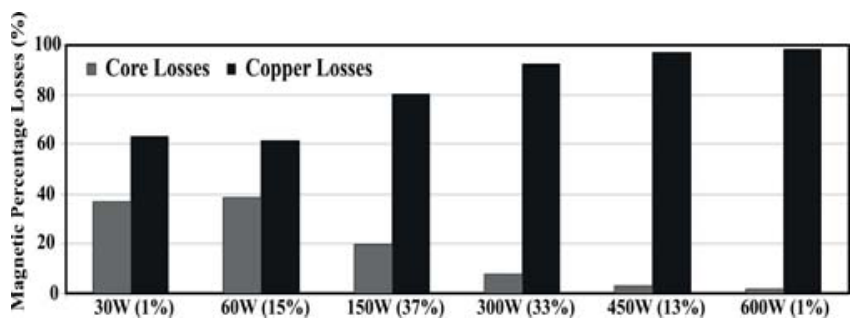

Fig. 10. Inductor percentage losses.

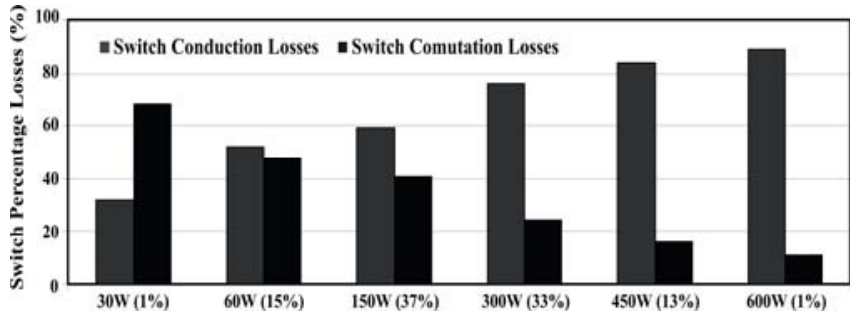

Fig. 10. Switch percentage losses

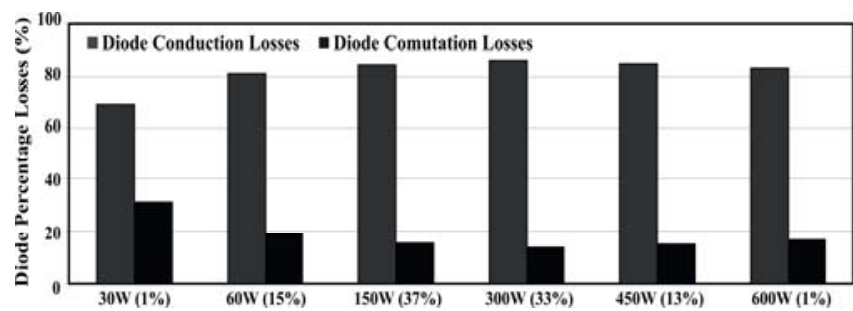

Fig. 10. Diode percentage losses.

The operation point selected has been (20\%@15 kHz) with a weighted average efficiency about 97.48\%. Experimental results were presented to validate the losses models, as well as to prove the weighted average efficiency of the selected operation point. The volume and cost were not considered in this work.

Finally, it was discussed, with an appropriate replacement of the devices part number (power switch and diode, magnetic materials, heatsink, capacitor and others components/dimensions as wire sections) could improve the weighted average efficiency of the designed converter. Furthermore, if other criteria are considered, in addition to efficiency, other operating points could be obtained.

\section{REFERENCES}

[1] International Energy Agency, " $\mathrm{CO}_{2}$ Emissions from Fuel Combustion - Highlights", 2013 edition.

[2] International Energy Agency, "World Energy Outlook 2013", 2013 edition. 
[3] D. Verma, O. Midtgard, T. O. Satre, "Review of photovoltaic status in a European (EU) perspective," in Proc. of PVSC, pp. 3292-3297, 2011.

[4] M. A. G. de Brito, L. P Sampaio, L. G. Junior, C. A. Canesin, "Research on photovoltaics: Review, trends and perspectives"," in Proc. of COBEP, pp.531 - 537, 2011.

[5] F. H. Dupont, C. Rech, J. R. Pinheiro, "A methodology to obtain the equations for the calculation of the weighted average efficiency applied to photovoltaic systems", in Proc. of INDUSCON, pp.1-8, 2012.

[6] R. F. Coelho, D. C. Martins, W. M. Santos, "Influence of power converters on $\mathrm{PV}$ maximum power point tracking efficiency", in Proc. of INDUSCON, pp.1-8, 2012.

[7] D. Sera, T. Kerekes, R. Teodorescu, F. Blaabjerg, "Improved MPPT Algorithms for Rapidly Changing Environmental Conditions", in Proc. of EPE-PEMC, pp.1614-1619, 2006.

[8] J. Kolar, J. Biela, J. Miniboeck, "Exploring the pareto front of multi-objective single-phase pfc rectifier design optimization - $99.2 \%$ efficiency vs. $7 \mathrm{~kW} / \mathrm{dm} 3$ power density," in Proc. of IPEMC, pp. 1-21, 2009.

[9] J. Biela, J. W. Kolar, G. Deboy, "Optimal design of a compact 99.3\% efficient single-phase PFC rectifier", in Proc. of APEC, pp.1397-1404, 2010.

[10] H. C. Sartori, F. Beltrame, J. R. Pinheiro, "A static converter comparative study taking into account semiconductor technologies and switch auxiliary circuits: Optimized design," in Proc. of COBEP, pp.280-285, 2011.

[11] D. Damasceno, L. Schuch, J. R. Pinheiro, "Design Procedure to Minimize Boost PFC Volume Concerning the Trade-offs Among Switching Frequency, Input Current Ripple and Soft-Switching", in Proc. of PESC, pp.2333-2338, 2005.

[12] International Electrotechnical Commission. IEC 61863: Photovoltaic systems - Power conditioners - Procedure for measuring efficiency. 1999.

[13] Magnetics ${ }^{\circledR}:$ 'Powder cores design manual and catalog'. Accessed on March 10, 2013. Available in: http://www.mag-inc.com.

[14] J. R. R. Zientarski, R. C. Beltrame, D. B. Cândido, M. L da S. Martins, H. L. Hey, "Design methodology for universal line input boost power factor correction magnetics", IET Power Electronics, vol.4, no. 6, pp. 715724, July 2011.

[15] M. Pieniz, J. R. Pinheiro, H. L. Hey, "An investigation of the boost inductor volume applied to PFC Converters", in Proc. of PESC, pp. 1-7, 2006.

[16] R. C. Beltrame, M. I. Desconzi, H. L. Hey, "Decentralized Multi String PV System with Integrated ZVT Cell”, in Proc. of CBA, pp. 1-8, 2010.

[17] U. Drofenik, J. W. Kolar, "A general scheme for calculating switching- and conduction losses of power semiconductors in numerical circuit simulations of power electronic systems", in Proc. of IPEC, pp. 1-8, 2005.

[18] H. C. Sartori, J. E. Baggio, J. R. Pinheiro, "A comparative design of an optimized boost inductor taking into account three magnetic materials technologies: Volume, cost and efficiency analysis", in Proc. of INDUSCON, pp. 1 - 6, 2012.
[19] B. W. Willians, Power electronics: devices, drivers, applications, and passive components, McGraw-Hill, 2nd Edition, New York, USA, 1992.

[20] HS Beneficiamento de Alumínio Ltda: 'Catálogo HS Dissipadores', Accessed on March 10, 2013. Available in: http://www.hsdissipadores.com.br.

\section{BIOGRAPHIES}

Fernando Beltrame, is an Electrical Engineering (2006) and Masters in Electrical Engineering (2009) from the Federal University of Santa Maria (UFSM). Currently, he is working toward the Ph.D. degree in electrical engineering in Federal University of Santa Maria. His areas of interest include power electronics, power factor correction (PFC), electromagnetic interference, optimized designs of static converters, and distributed generation among others.

Fabrício Hoff Dupont, received the B.S. degree in telecommunications engineering from the Regional University of Blumenau (FURB), Blumenau, Brazil, in 2007, and the M.S. degree in electrical engineering from FURB, in 2010. Currently, he is working toward the Ph.D. degree in electrical engineering in the Federal University of Santa Maria, Santa Maria. His research interests include modeling and control techniques of static converters, fuel cells, photovoltaic cells, fuzzy logic, and genetic algorithms.

Hamiltom Confortin Sartori, is an Electrical Engineering (2007), Master in Electrical Engineering (2009), and Doctor in Electrical Engineering (2013) from the UFSM. His current research interests include optimized designs of static converters, UPS, magnetic designs, power semiconductors (selection, losses analysis and system design of heat transfer) and electromagnetic compatibility.

Leandro Roggia is an Electrical Engineering (2008), Master in Electrical Engineering (2010), and Doctor in Electrical Engineering (2013) from the UFSM. Since 2013, he has been a professor at UFSM - Industrial Technical College of Santa Maria. His current research interests include power electronics, DC-DC converters, energy storage devices, distributed generation, and microgrid systems, among others.

Everton Cocco Cancian, is Electrical Engineering student from the UFSM. His current research interests include electromagnetic interference, distributed generation among others.

José Renes Pinheiro, received the B.S. degree from the UFSM, and the M.S. and Ph.D. degrees from the Federal University of Santa Catarina, Florianopolis, Brazil, in 1981, 1984, and 1994, respectively, all in electrical engineering. Since 1985, he has been a Professor at the UFSM, where, in 1987, he founded the Power Electronics and Control Research Group. He was the Technical Program Chairman of the 1999 Brazilian Power Electronics Conference and of the 2000 and 2005 Power Electronics and Control Seminar. From 2001 to 2002, he was with the Center for Power Electronics Systems, Virginia Polytechnic Institute and State University (Virginia Tech), Blacksburg, as a Postdoctoral Research Scholar. He has authored more than 200 technical papers published in the proceedings of conferences and journals. His current research interests include high-frequency and high-power conversion, power supplies, multilevel converters, and modeling and control of converters. 